\title{
ADVANCES IN NATURE CONSERVATION IN LESOTHO
}

\author{
R PHILLIPS*
}

\author{
Chief Project Officer \\ Ministry of Community and Rural Development \\ PO Box 686 \\ Maseru \\ Lesotho
}

Lesotho is an independent enclave within the Republic of South Africa. It is roughly the size of Belgium and has a population of approximately one million. Prior to independence (4 October 1966) no official action had been taken toward nature conservation. Priority had been given to rural development schemes, improvement of agricultural practices, and to urban and industrial development.

In July 1968, the Minister to the Prime Minister, the Hon Chief Patrick 'Mota, the minister responsible for tourism, requested that proposals be submitted for the implementation of Lesotho's first national park. The area suggested and provisionally accepted was the $\mathrm{Ox}$ Bow area in north-west Lesotho. However, a memorandum was submitted in November 1968 suggesting that Sehlabathebe, in the south-east, should receive consideration. On the 8 May 1969 during an on site visit by the Deputy Director of the South African National Parks Board, who was Lesotho's first advisor on national parks, and the Parks Advisory Committee, it was decided that Sehlabathebe should become Lesotho's first national park.

Thus Sehlabathebe National Park (SNP) came into being without prior planning and staff. Since the SNP is synonymous with nature conservation in Lesotho this paper will be devoted to Sehlabathebe. The future of nature conservation in Lesotho depends upon the success of the park. Credit must be given to those members of the government of Lesotho who had the foresight and initiative to put aside 6500 ha of mountain grazing land for conservation purposes in a country where land is at a premium and in a day and age when many developing countries were paying little heed to the need for conservation. From its inception the SNP has received the full support and personal interest of the Prime Minister, the Rt Hon Dr Leabua Jonathan and the Hon Chief Patrick 'Mota, the two men who can be regarded as the founding fathers of nature conservation in Lesotho.

The climate is generally cool to cold throughout the year. Rainfall

*Present address: Plot 714, P.O. Southbroom 4277. 
occurs mainly in the summer and mist is common. Temperatures may vary seasonally from approximately $30^{\circ} \mathrm{C}$ in the summer to $-15^{\circ} \mathrm{C}$ in winter. Strong winds are frequent the year-round.

Sehlabathebe's 6500 ha consists of mountainous grassveld on a high plateau whose average height above sea level is 2400 metres. This plateau, from which the name Sehlabathebe is derived (plateau of the shield), is the headwater catchment area of the Tsoelikana River. The Cave Sandstone is the primary geological feature of the park. In many areas, Cave Sandstone formations protrude through the shallow sedimentary soil layer. Wind and water erosion has created from these formations numerous arches, caves and pools. A network of dolerite dykes exist along with one recently reported kimberlite fissure. In addition, there is Red Bed shale and basalt within the park.

Little is known about the indigenous fauna of Sehlabathebe. Although some species of large mammals such as the vaal rhebuck, eland, oribi, and small cats have been sighted, it is speculated that past human pressures are responsible for presently limited populations. Populations of smaller mammals seem to be flourishing. Species are yet to be identified.

Bird life within the SNP is abundant. Conspicuous species are the rock jumper, bald ibis, cape vulture, jackal buzzard, lammergeyer, and such migratory birds as the white stork, black-headed heron, crowned crane, and yellow-billed duck. Various species of hawks are predominant as well. A relationship between large populations of smaller mammals and the prominence of birds of prey is assumed.

The indigenous vegetation of the SNP is characterized as mountainous grassveld. In addition to grasses there are numerous species of composites, scrophs, lilies, orchards and sedges.

The technical team of the Department of Community and Rural Development of Lesotho, was given the task of developing the national park. Already a presence in the area with a technical staff and equipment, the team undertook the initial construction work within the park. It must be stated in retrospect, that in the early stages of development mistakes were probably made, but these are mistakes that can be rectified and perhaps it was better to endeavour and make mistakes rather than to remain totally inactive while awaiting funds, staff, and expertise that might have been years in forthcoming. The SNP came into being at a time that was propitious to a project such as this and had initial development awaited the adoption of an overall master plan, the prevailing conditions might not have been as favourable for its inception.

With the strong support of the Deputy Chief Director of the National Parks Board of South Africa, the South African Nature Foundation was approached for funding development projects at Sehlabathebe. An initial R17 000 was granted to start the construction of a perimeter fence of acceptable standard. Additional grants of R35 000 and R3 000 were 
made for the completion of the $40 \mathrm{~km}$ perimeter fence and for the construction and equipping of a research laboratory. Apart from a 4,8 $\mathrm{km}$ gap in the fencing along the international boundary, these projects have been completed. In addition to the initial construction work, the Lesotho Government input has consisted of the construction of a luxury lodge accommodating up to 12 people, hostel facilities for school groups and climbing parties, and a mountain hut capable of accommodating two parties of six each. Further development awaits the completion and adoption of a master plan.

The Chief Project Officer of the Department of Community and Rural Development is the designated government officer responsible for the development of the park. He is assisted by qualified United States Peace Corps personnel. Presently local staff is limited to park ranger and labourer activities but steps are underway to recruit suitably qualified Basotho for in-service training in park management and administration.

Visiting specialists have provided the SNP staff with valuable advice. Additional support has been provided by park visitors monitory-wize.

This is where the SNP stands at the moment, about to take its rightful place among the outstanding natural areas of the world. Perhaps to those who have been associated with its development the following words can be regarded as being their guide: "The past is our refuge, the present our opportunity and the future our hope". The terms of reference for the establishment of the SNP were vague to the extreme as was Lesotho's concept of just what nature conservation involved. But SNP and Lesotho's conservation awareness have developed side-by-side. Future development will be such that expanding visitor facilities will not be detrimental to the park's unique position as a conservation area for Lesotho.

Essential to the park's future development is the construction of an all weather road via Bushman's Nek. This road will provide a direct link between Natal and its mountain resorts and the park. At the present time visitors are able to reach the park by horseback, by air and by road. Opportunities for hiking and climbing are year-round attractions at Sehlabathebe.

In the streams of the SNP Oreodaimon quathlambae, a unique cyprinid fish endemic to Lesotho occurs (a Red Data Book species, listed by the IUCN in 1971). This species was originally described from the Umkomazana River, Natal, by Barnard in 1938 but was subsequently lost to science. In 1970 the species was rediscovered in the Tsoelikana River, Sehlabathebe, along a $7 \mathrm{~km}$ stretch within the park.

Perhaps the SNP's greatest treasure is its unique flora. Although the park lies within a narrow altitudinal range and does not cross the sandstone - basalt boundary, topographic variations within the park has produced a wide variety of habitats. Two botanists resident in the park are presently cataloguing all species of vascular plants, mosses and lichens. 
The crown jewel of the Sehlabathebe flora is Aponogeton ranunculiflorus Jacot Guillarmod and Marais. Unknown to science prior to 1970 it was first noted by a young British botanist Miss Kate Williamson who sent specimens to Kew Gardens. Not only is the SNP the type locality of this species but at present the rock pools in this area of the park and a few pools just across the border in neighbouring Natal comprise the total known distributional range of $A$. ranunculiflorus. It is not presently known whether this rare endemic is a relic species or a more recently evolved species but its presence alone would seem justification enough for the park's existence.

Although endemic of the Mountains of Lesotho, A. polyphylla is not found in the native region of the SNP. However, specimens have been planted in the country's only national park where they can be seen by visitors and where they will be safe from plant collectors.

The greatest threat to the survival of any species, plant or animal, is the destruction of its habitat. Thus the most important contribution made to the conservation and preservation of the fauna and flora of the SNP, and indeed of Lesotho as a whole, was the fencing of the parkland during 1972-1974. While still allowing vaal rhebuck access to the park the fence has generally been effective in excluding cattle, sheep and goats from grazing on the parkland and has thus allowed many plant species to develop fully and set seed that would not have been able to do so under heavy grazing. The fencing-out of cattle, sheep and goats has also allowed for some heavily eroded areas along the old animal tracks to become stabilized by pioneer plant species. In other areas overgrazing prior to the establishment of the park has led to changes in the species composition and degree of vegetation cover.

A second factor related to plant conservation has been the non-usage of burning as a management tool. This "hands-off" policy has not been entirely successful as arsonists have been responsible for widespread fires in the park in past years. However, as the park comes to be accepted as such by the local inhabitants, the incidences of arson will probably decrease. Accidental fires ignited in adjoining areas will continue to be a possibility.

The continued absence of a management burning plan will allow the natural course of succession to proceed uninterruptedly and thus a climax community could result. Attainment of this state would make the park unique among the readily accessible lands in the mountain areas of Lesotho. In order to assess changes in vegetation permanent study plots have been established at several sites representative of the varying topographic and edaphic conditions encountered. These studies will provide data on which management decisions can be based and information useful in developing park interpretative programs. They will add to the general scientific knowledge of the floristics and population dynamics of the park.

The next two years are of vital importance to nature conservation in 
Lesotho. A master plan for the park is being written but it must be finalised, adopted, and implemented. Adequate funding must be obtained, legislation already written must be gazetted, and a parks board of knowledgeable persons must be appointed. Negotiations for the construction of an all weather road linking the park to Natal are in the advanced stages. A site has been selected, and initial funds allocated, for an airstrip at the park. Educational programs need to be prepared in order to explain the purpose and value of parks and nature conservation to the citizens of Lesotho.

Future conservation efforts in Lesotho include plans for a detailed study of the distribution, life history and population dynamics of Aloe polyphylla. and investigation of the entire Drakensberg escarpment in order to put forward proposals for the establishment of a conservation area complementary to the wilderness area below, and feasibility studies for the establishment of additional parks and/or nature conservation areas, e.g. Maletsunyane Falls and Ongeluks Nek.

Much remains to be done. Dedication on the part of a few is required and an interest on the part of many is essential. I should like to leave you with the words of Lynton K Caldwell: "Governments not only have a responsibility to establish national parks and equivalent reservations for protection of man's natural and cultural heritage, but they have the more difficult responsibility thereafter to honor this commitment in the practical task of administration". 